\title{
Measuring Quality in Indian VET Institutions: Development Steps Towards a Framework Adapted to the National Context
}

\author{
Muthuveeran Ramasamy*, Julia Regel, Harshil Sharma, Anjana \\ Rajagopalan, Matthias Pilz \\ Chair of Economics and Business Education, University of Cologne, Herbert-Lewin-Straße 2, \\ 50931 Cologne, Germany
}

Received: 31 October 2020, Accepted: 01 March 2021

\begin{abstract}
Purpose: The quality of vocational education and training (VET) processes plays an important role in international education policies and research. In India, issues of quality came into focus in recent years due to an increased demand for skilled workers, and continuing challenges in the area of quality of VET. Existing quality assurance mechanisms of VET in India are characterised by a lack of comprehensiveness and uniform standards. This paper addresses the contextualised development of an Indian-specific approach for quality measurement. It centres on following research question: Which quality areas, criteria and related indicators are of relevance for measuring quality comprehensively?

Approach: Design-based research substantiates the research objective, which is to develop a model that is theoretically and technically sound, as well as adapted to the national context. The question of how to create "cultural-fit" was essential for the research process illustrated in this paper. Starting point for the development of the approach was to build a structured review, and following analysis, with reference to existing models and approaches to quality management. The initial search examined national and international academic sources for quality management in business and education, as well as governmental sources for quality management strategies in VET. A significant number of models were selected, based on inclusion criteria, and these models were aggregated to provide a source for a first own conception of an approach.
\end{abstract}

*Corresponding author: muthu.ramasamy@uni-koeln.de 
Results: Quality dimensions and criteria were collected and identified with reference to distribution across models. In total, seven major quality areas are identified, namely Institutional Sphere and Context; Personnel; Educational Planning, Provision and Assessment; Learning and Teaching; Leadership and School Management; Industry Linkage and Learner Achievements. In addition, 40 quality criteria are determined under these major quality fields, and relevant quantitative and qualitative sub-indicators for measurement are derived.

Conclusion: The actual results will be a basis for the following pilot-based implementation in India. The model can provide meaningful feedback and data-based recommendations for continuous improvement of the Indian VET system and may furthermore provide for a reflected and contextually adapted implementation in other countries

Keywords: Quality, Vocational Education and Training, VET, India, Polytechnic Colleges, Industrial Training Institutes

\section{Introduction}

While Indian economic growth has been consistently high during the last three decades, the country is currently in a position where both the employers requiring skilled workers on an intermediate level, and those seeking employment, are facing issues (Kumar et al., 2019; Ramasamy \& Pilz, 2020). Because vocational education and training (VET) programmes have gained a place of national importance as a means for gaining employment (Kumar, 2016; Mehrotra et al., 2013; Pilz, 2016b), it becomes imperative for VET institutions to nurture trained and skilled manpower, to meet the demands of different sectors of the economy (Goel, 2011; Ramasamy \& Pilz, 2019).

The VET system in India operates through the following four major modes, namely:

1. Secondary and higher secondary schools and Polytechnic Colleges,

2. Industrial Training Institutes (ITIs) which may be public or private,

3. Private training institutes under the National Skill Development Corporation, and

4. Apprenticeship training in different schemes under the Apprentices Act.

Among these, ITIs and Polytechnic Colleges (which may be public or private) are of major relevance in the sector (Agrawal, 2012; Malik \& Venkatraman, 2017). Both institutions stand for different strands of formal VET in India which can be categorised into vocational education and vocational training, the two sections being managed by different ministries. 
At the level of higher technical education, Polytechnic Colleges in India have recently been structurally affiliated to the Ministry of Skill Development and Entrepreneurship (MSDE) in relevant sub schemes (MSDE, 2020). However, until September 2018, Polytechnics in India were administered by the Ministry of Human Resource Development $\left(\mathrm{MHRD}^{1}\right)$ and accreditation processes and curricula are to date still regulated by the All India Council for Technical Education under the MHRD.

Over the past two decades, the Indian government has made several efforts to increase the quantity of formal VET measures. Thus, the number of ITIs in India has grown dramatically across the country, from under 2,000 in 2007 to 14,779 in 2020, of which 11,715 are private (MSDE, 2021). The increase in the number of private ITIs has been much greater than that of public ITIs (MSDE, 2015).

In 1947 there were 43 Polytechnic colleges with an intake capacity of 3,400 students, and by 2018 there are around 3,440 Polytechnics in India with an intake capacity of 1.5 million students (MHRD, 2019). Nevertheless, although Polytechnics have an essential role, they have not been a main focus of research on the VET system in India (Schneider \& Pilz, 2019; Venkatram, 2016). By reason of limitations of space and a different focus for this paper, the section on VET in India will not be further elaborated here. For general information about the Indian VET system, refer to overviews of Pilz (2016a), Wessels \& Pilz (2018) and British Council (2016).

The ITIs and Polytechnics in India are facing a number of problems in terms of quality (Goel, 2011; Kumar et al., 2019; Mehrotra, 2014a) which will be discussed in the following sections. In order to avoid the risks inherent in the rapid increase of VET institutions over the past decade (see MSDE, 2015; Venkatram, 2016), stringent regulation and a nationally unified quality assurance system is vital. Consequently, in 2017, the MSDE launched the National Quality Assurance Framework (NQAF) aimed at improving the quality of all education and training and skills programmes in India. But, at this stage, no empirical evidence as to the extent of implementation and outcome of NQAF is found. Thus, measuring quality comprehensively is important for the VET system in India, where not much research has been carried out. This research gap, owing mostly to gaps in data and measurement issues, thus needs to be targeted.

The overall objective of the research project discussed here is to address the need for significant data collection and to design a comprehensive approach to quality measurement in ITIs and Polytechnic Colleges in India. Research and development activities focus on the micro (teaching and learning processes) and meso (organisational/institutional) level of VET institutions in contrast to approaches that target the system- and thus national level of educational governance. Hence, an approach is to be developed that provides for bottom-up processes of institutional development and may be used for external and internal evaluation.

1 The name of the Ministry of Human Resource Development (MHRD) was changed to Ministry of Education in August 2020 (MHRD, 2020). However, the authors use the prior term MHRD in this article. 
This paper addresses the first steps of the design of the approach for comprehensive quality measurement. It focuses on the development of quality areas, criteria and related indicators, to build a framework that is theoretically and technically sound as well as adapted to the Indian context.

\section{Quality of VET in India: Current Status and Challenges}

The quality of VET is frequently highlighted in view of globalised economies and the competitiveness of nations (European Centre for the Development of Vocational Training [CEDEFOP], 2009; Watters, 2015), the systems of education and training being regarded as "the most critical" condition (Galvao, 2014, p. 5) for development and growth of countries around the world. Regarding quality assurance in VET, recent and ongoing international developments concern the establishment of national qualification frameworks, the internationalisation of national qualifications (Watters, 2015), as well as the implementation of quality management approaches in education (Galvao, 2014), like ISO 9000 or other Total Quality Management based models. These developments in VET are partly reflected in Indian educational policies, but in reality are implemented to different degrees.

\section{Quality Issues in Indian VET Institutions}

In India, ITIs are perceived as having a lower standing from a social point of view (Agrawal \& Agrawal, 2017; Ajithkumar \& Pilz, 2019). In addition, the quality issues of VET institutions in India are of great concern, and reforms have been introduced to address the challenges of both increasing the employment opportunities by upskilling a large percentage of young people, and to ensure availability of a skilled workforce to meet regional and national labour market demands (Kotamraju, 2014; Majumdar, 2008; Mehrotra, 2014b; Pilz \& Gengaiah, 2019; Ramasamy \& Pilz, 2019). Nevertheless, many studies (Agrawal \& Agrawal, 2017; Neroorkar \& Gopinath, 2019; Rao et al., 2014; Schneider \& Pilz, 2019; Tara et al., 2016; Zenner et al., 2017) have pointed out that ITI graduates have very low employability due to factors such as poor resources, outdated curricula, the competence of teaching staff and obsolete equipment in the VET institutions.

A study by Mehrotra et al. (2013), surveyed 43 companies in the states of Karnataka, Maharashtra and Tamil Nadu and found that most of the firms pointed out that their employees came without practical skills, but well versed in theory. In addition, the study by Tara et al. (2016) on the quality of state-run ITIs in Karnataka, Orissa, Tamil Nadu and New Delhi, found that the ITIs have not been meeting the required quality standards, and focus only on theory rather than practical components, with little or no relation to practice or modern technology. They also concluded that infrastructure and equipment in ITIs were inadequate (Tara et al., 2016). 
The study conducted by Mehrotra et al. (2014) also found that the majority of students who graduate from Polytechnics lack application-oriented knowledge and problem-solving skills, and could, therefore, not meet the demand of industrial skills. Rao et al. (2014) noted a similar view, that employers are not satisfied with ITI graduates as they lack in technical skills, practical skills and soft skills. Studies revealed that a large percentage of ITI graduates in India face major difficulties in entering the labour market or even remain unemployed despite of their training certificate (Ajithkumar \& Pilz, 2019; Joshi et al., 2014; Neroorkar \& Gopinath, 2019; Prakash \& Gupta, 2002).

Another major problem in VET institutions is the availability of qualified instructors (Ajithkumar, 2016). Many instructors had not received any pedagogical training, are not prepared enough for teaching (Jambo \& Pilz, 2017; Pilz \& Gengaiah, 2019; Zenner et al., 2017) and were employed on a part-time or term contract basis, which again turned out to be an issue impacting teaching and learning.

A study by Tara et al. (2016) found that $50 \%$ of the principals interviewed at government ITIs, responded that they had difficulty in finding qualified trainers, and therefore they are forced to employ temporary instructors lacking in adequate skills, which impacted the teaching and learning process. They further argue that "if the teaching is of poor quality, and the competences taught in the ITI programmes are not meeting the needs of the labour market, vocational training will not be recognised by employers as suitable" (Tara et al., 2016, p. 11).

As Joshi et al. (2014) claim, qualified and motivated teachers and instructors are the bottom line of any training system, and the standard of teaching and training personnel is one of the key indicators to measure the quality of training. There is a huge demand for teachers/ instructors in the country's VET system (Mehrotra, 2014b) which is substantiated by official numbers of the MSDE, reporting 95,000 vacant instructor positions in ITIs in 2020. However, despite of several government efforts to qualify higher numbers of instructors, the present capacity for the training of trainers under the Craft Instructor Training Scheme (CITS) is 7,776 per annum only. Furthermore, seats are frequently not completely filled and utilisation numbers did even decrease by $4 \%$ to $81 \%$ from 2017 to 2019 (MSDE, 2018; MSDE, 2020). Currently, only $15 \%$ of the teaching and training personnel in ITIs has a CITS certification. One reason of trainer shortage lies within insufficient capacities for training. However, other factors can be identified in a complex interaction of the low attractiveness of the vocational education and training system and hence respective teacher positions, entry requirements for CITS training (see MSDE, 2020), and working conditions that need improvement, especially in private ITIs (Pilz \& Gengaiah, 2019; Tara et al., 2016). The shortage of (qualified) trainers has major implications on the actual quality of training. Addressing input factors such as the quality of instructors, which impacts directly on learning outcomes, and thus employability, is a great challenge. This can be resolved only if the training quality is enhanced by making 
provision for development of well-trained teachers and instructors, with pedagogical skills and experience from the world of work (Mehrotra, 2017; Pilz \& Gengaiah, 2019).

The above literature review reveals that despite various skill development initiatives by the government at state and federal level, VET institutions in India suffer due to a range of issues. This affects the overall functioning and quality of vocational training institutions in India (Agrawal \& Agrawal, 2017; De, 2019); hence, there is a need for regulation and strengthening of the VET system by ensuring quality training (Chakravorty \& Bedi, 2019; De, 2019).

\section{Development Process of Model Design}

Institutional quality management based on comprehensive models to initiate and steer educational and organisational development processes, as well as a general "culture of quality", are not well-established in the context of VET in India (Tara et al., 2016). The transfer of educational systems and practices is subject to context-dependent difficulties and obstacles that cause demand for contextualisation (Broadfoot, 2000; Vogelsang \& Pilz, 2020). Crossnational policy borrowing frequently involves processes of adaptation (Phillips \& Ochs, 2003), and often policies cannot be transferred entirely (Li, 2017; Pilz, 2017).

The current approach is based on a concept of prospective evaluation (Li \& Pilz, 2019) in the form of an extensive pilot-based test to substantiate and enable a successful transfer of the model. Furthermore, it incorporates cultural and practical adaptation processes from an early stage of development, blending theoretical, practical and culture-specific aspects of development. Therefore, a research approach was chosen that provides for openness and flexibility, allows for a continued cycle of development, and the integration of practical experience within the research process.

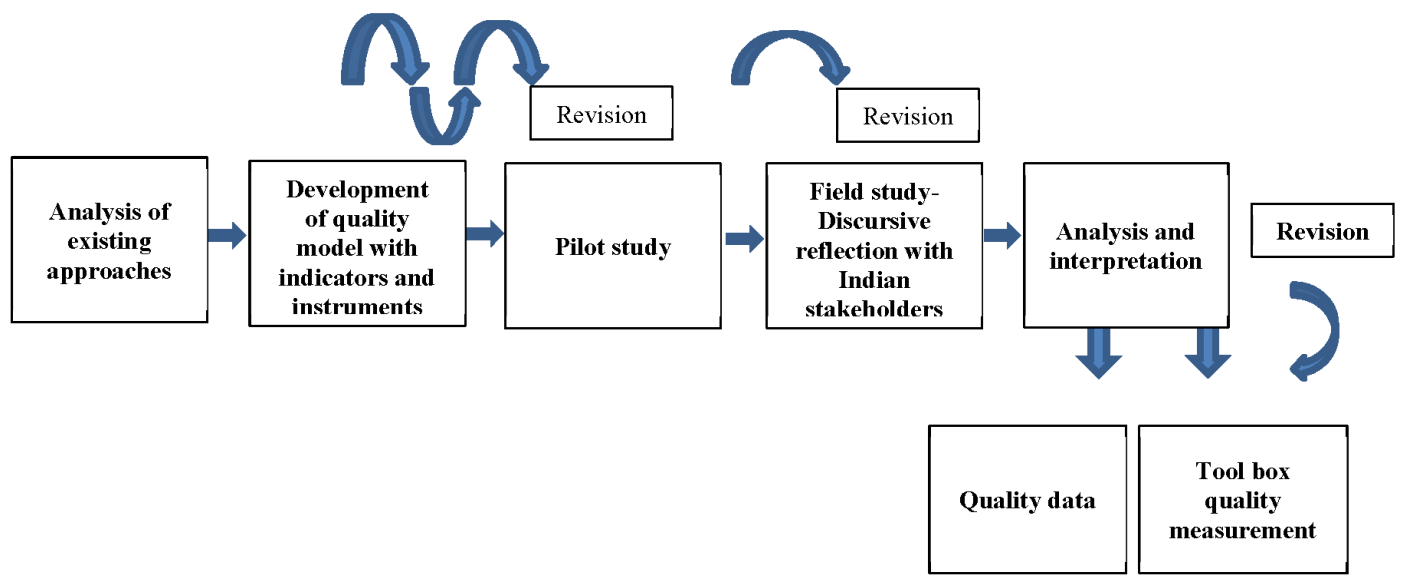

Figure 1: Development Process of Quality Model 
The paradigm of Design-Based Research (DBR) builds the foundation for recurrent processes of analysis, design, evaluation and revision of the concept, as it considers the practical approach and relevance (Design-Based Research Collective, 2003; Euler, 2014) of the development objective. The chosen methods were shaped around the overall aim, to develop a model that is technically sound, as well as adapted to the cultural and socioeconomic context. DBR investigates "the manner in which the desirable objective can best be attained in a given context through an intervention yet to be developed" (Euler, 2014, p. 17). Thus, research steps and processes were guided by the need to balance and combine scientific necessities, the integration of practical necessities and realisation of "cultural-fit" (Lewis, 2007). The core research group consisted of Indian as well as German researchers who worked constantly in a bilateral team. Two guest researchers from India were invited to join the project; they spent time with the research group at the University of Cologne, and assisted with field research in India. In addition, four Indian project partners from relevant areas, served for constant intercultural and professional feedback (Pilz et al., 2020). The specific composition of the research team as well as the close cooperation with Indian universities and project consultants enables genuine ownership of the model. Such collaboration in design-based research allows practitioners and researchers to work together to bring about meaningful changes in the context of practice, and helps to refine key components of an intervention (Design-Based Research Collective, 2003).

The first steps of model development involved the elaboration of a theoretical and conceptual base, guided by reciprocal processes of convergence and alignment. These were deliberately structured by oral and written communication and mediation processes.

Taking an organisational perspective to educational institutions, an extensive literature search was conducted, with a focus on national and international quality management approaches in education. Relevant approaches were identified, analysed and summarised. Existing models of school quality, were selected according to deductive and inductive criteria, in order to create a basis for the development of an own approach. Criteria utilised relate to the acceptability (Proctor et al., 2011) of the approach in the Indian context, comprehensiveness (Alexander, 2008) and overall elaboration of the model, as well as the conceptual base of models.

Thus, for example, a one-sided concentration of models from German-speaking countries was avoided; instead, internationally recognised, and extensively implemented frameworks, relevant models from Asia, as well as indigenous Indian approaches were included. A total of 44 models were identified and analysed, out of which 14 models were selected for further aggregation. These jointly provide a sound basis for measuring quality, base on a complex and multilevel quality construct, and correspond to the underlying understanding and definitions of educational quality. The approach was supplemented by an extensive literature review, and collection of findings from international school effectiveness and school improvement 
research, as well as research into teaching and learning. Indian national education policy and pedagogic research sources, were collected and reviewed in order to specifically include national approaches so as to address significant cultural context and premises (Broadfoot, 2000), and reduce the risk of ethnocentrism (Alexander, 2008, p. 40). By analysis of the selected models, core areas of school quality were identified and consolidated in an iterative process. The adoption of the system and nomenclature of a specific approach was avoided for matters of accessibility, acceptability (Proctor et al., 2011) and connectivity. Institutional core areas of educational quality were merged with respect to broad but consistent fields of organisational actions and processes, to enable a potential subsequent alignment to different quality management approaches. Countries across the world have distinct VET and labour market practices and, based on the industrial growth and socio-economic development of the respective countries, they ascribe a different meaning to the concepts and approaches to the VET system (see CEDEFOP, 2009; Pilz \& Li, 2014; Winterton, 2012). Consequently, approaches to quality management, definitions and context, vary according to the culture of the specific country; VET policy, framework, institutional structure and educational system. Thus, a specific consideration of existing Indian models and country-specific needs, guided by intercultural feedback from the Indian research partners, lead to the definition of a main quality area relating to the involvement of the private sector in vocational training and education. In the next step, selected models served for the identification and analysis of quality criteria.

By comparing and aggregating more than 400 indicators and criteria, main criteria and related indicators were identified, evaluated and bundled in a staggered process. A primary selection feature related to the applicability of criteria (Alexander, 2008) with respect to their fit regarding necessities and potentials for measurement at the targeted system level. For the current purpose, criteria had to be selected that target the meso and micro level of the VET system. Aspects were chosen that have the potential to be influenced by individual institutions, in order to provide for a developmental function of the framework. As a next step, further selection features were developed with regard to acceptability (Proctor et al., 2011), social validity (Nastasi \& Hitchcock, 2016), feasibility and appropriateness (Proctor et al., 2011) of criteria. Acceptability was, among others, related to relevance regarding identified problems of the VET system, fit with regard to systemic features and national requirements, as well as compliance with the underlying quality definitions. Social validity addressed content-related aspects regarding culture-specific contexts and values, with regard to the target group. Feasibility included aspects of measurability, data access and the competencies of stakeholders in the intervention setting. Appropriateness was considered separately, as criteria or entire approaches may be accepted but can still prove inappropriate, for example with regard to resources and structures on site or individual needs of consumers or organisations (Proctor et al., 2011). Aspects of the contextual and cultural fit of criteria, related to the complexity of quality aspects (e.g. measuring social competences), linguistic changes with regard to the fundamental understanding 
of the content, or negative connotations due to current systemic problems (e.g. the notion of "recognition of prior learning", which is basically perceived as a policy facet), aspects that are culturally considered unsuitable (e.g. promotion of learner self-assessment) or the transfer of Western pedagogical concepts that have no meaning, or a different meaning in the national context (e.g. the German notion of work-process orientation as a pedagogical concept). Here, it needs to be underlined that the omittance of specific terms and concepts like, e.g., the German "vocational concept" which, among others, comprises a highly holistic understanding of the notion of "occupation", does not necessarily lead to a low comprehension and likewise reduced construction of the concept of educational quality. In the past, there have been many attempts by Indian educational authorities to import elsewhere successful policies as part of VET and general education reform efforts (see e.g. Brinkmann, 2015; Mehrotra et al., 2014). However, those attempts, e.g. the expansion of dual apprenticeship structures following the German dual system, could not be implemented as intended until today- or stayed on the level of theoretical policy recommendations (see e.g., Mehrotra et al., 2014). These examples from the Indian context are in line with general findings from educational policy transfer research that show that the export or import of foreign models does not prove successful without appropriate contextualisation (Li, 2017; Steiner-Khamsi, 2012). The approach taken here involves a contextual and cultural adaptation that enables a successful transfer of the model, but does not alter the core component of the approach (Nastasi \& Hitchcock, 2016), which is to measure educational quality comprehensively, according to a holistic and empirically substantiated definition of VET quality. Therefore, 40 criteria of school quality were determined, which were underpinned by further qualitative and quantitative sub-indicators. This process of selection and elimination enabled the researchers to identify relevant contextual factors, and enhanced the researcher's understanding of the intervention (Design-Based Research Collective, 2003).

\section{$4 \quad$ Structure and Content of the Model}

The basic structure of the model integrates input, process and output, as well as outcome factors of educational quality (see Heneveld \& Craig, 1996; Scheerens \& Bosker, 1997; United Nations Educational, Scientific and Cultural Organization, 2002) that have been transferred into quality criteria, and supplemented with respective indicators. The underlying approach was extended and systematised by means of an organisational perspective to institutional management and quality. The model encompasses seven areas of institutional quality in vocational education and training. Six areas relate to characteristics of institutional processes and themes, while one additional area addresses results and outcomes with a focus on learner achievements. Areas include: Institutional Sphere \& Context; Personnel; Educational Planning, Provision \& Assessment; Learning \& Teaching; Leadership \& School Management; Industry Linkage and Learner Achievements. 


\begin{tabular}{|c|c|c|c|c|c|c|c|}
\hline & $\begin{array}{c}1 \\
\text { Institutional Sphere \& } \\
\text { Context }\end{array}$ & $\begin{array}{c}2 \\
\text { Personnel }\end{array}$ & $\begin{array}{c}3 \\
\text { Educational Planning, } \\
\text { Provision \& Assessment }\end{array}$ & $\begin{array}{c}4 \\
\text { Learning \& Teaching }\end{array}$ & $\begin{array}{c}5 \\
\text { Leadership \& School } \\
\text { Management }\end{array}$ & $\begin{array}{c}6 \\
\text { Industry Linkage }\end{array}$ & $\begin{array}{c}7 \\
\text { Learner Achievements }\end{array}$ \\
\hline Input & $\begin{array}{l}1.1 \text { Facilities \& Resources } \\
\text { - General Facilities } \\
\text { - Learning Facilities \& } \\
\text { Resources } \\
\text { - Resource Management }\end{array}$ & $\begin{array}{l}\text { 2.1 Personnel Competence \& Attitude } \\
\text { - Educational Personnel Qualification } \\
\text { 2.2 Working Environment \& Job } \\
\text { Security } \\
\text { - Working Conditions Teaching Staff } \\
\text { - Working Conditions Non-teaching } \\
\text { Staff } \\
\text { 2.3 Training \& Development } \\
\text { - Investment \& Engagement in } \\
\text { Training } \\
\text { - Further Training }\end{array}$ & $\begin{array}{l}\text { 3.1 Educational Provision } \\
\text { \& Curricula } \\
\text { - Demand-Orientation of } \\
\text { Course Programme } \\
\text { - Quality School Syllabus } \\
\text { 3.2 Assessment Concept } \\
\text { \& Practices } \\
\text { - Regular Assessment } \\
\text { - Holistic Assessment }\end{array}$ & & $\begin{array}{l}5.1 \text { Effective Institutional } \\
\text { Organisation } \\
\text { - Supportive \& Efficient } \\
\text { Institutional Processes }\end{array}$ & & \\
\hline Process & $\begin{array}{l}1.2 \text { Student Support \& } \\
\text { Provisions } \\
- \text { Student Support Services } \\
\text { - Pre-enrolment \& Career } \\
\text { Counselling } \\
\text { 1.3 Inclusion, Access \& } \\
\text { Equity } \\
\text { - Availability \& Assis- } \\
\text { tance: Schemes for VET } \\
\text { Access } \\
- \text { Participation of Under- } \\
\text { represented Groups }\end{array}$ & $\begin{array}{l}\text { 2.4 Cooperation \& Teamwork } \\
\text { - Cohesion \& Cooperative Teamwork }\end{array}$ & & $\begin{array}{l}\text { 4.1 Quality Classroom Teaching \& Management } \\
\text { - Lesson Preparation } \\
\text { - Appropriate Methodology Mix } \\
\text { - Transparency \& Structure } \\
\text { - Active Learning Activities \& Time } \\
\text { 4.2 Learner Orientation } \\
\text { - Learning Climate } \\
\text { - Frequent Individual Feedback } \\
\text { - Individual Support \& Differentiation } \\
\text { 4.3 Holistic Vocational Focus } \\
\text { - Practice \& Occupation Orientation } \\
\text { - Knowledge Application \& Recontextualisation Focus }\end{array}$ & $\begin{array}{l}5.2 \text { Effective \& Cooperative } \\
\text { Leadership } \\
\text { - Institutional Strategy \& Vision } \\
\text { - Cooperative Leadership } \\
5.3 \text { Quality Assurance \& } \\
\text { Development } \\
\text { - Quality Management Initiatives } \\
\text { - Evaluation \& Improvement of } \\
\text { Educational Quality } \\
\text { 5.4 External Relations \& Com- } \\
\text { munication } \\
\text { - Public Relations }\end{array}$ & $\begin{array}{l}\text { 6.1 Industry Engagement } \\
\text { - Identification of Industrial } \\
\text { Training Needs } \\
\text { - Industry Engagement } \\
\text { - Functioning IMC Commit- } \\
\text { tee (ITI only) } \\
\text { 6.2 Placement Coordination } \\
\text { \& Monitoring } \\
\text { - Functional Placement \& } \\
\text { In-service Coordination }\end{array}$ & \\
\hline $\begin{array}{l}\text { Output/ } \\
\text { Outcome }\end{array}$ & & & & & & & $\begin{array}{l}\text { 7. } 1 \text { Competencies \& } \\
\text { Qualifications } \\
\text { - Employability } \\
\text { - Learner Performance } \\
\text { 7.2 Transition \& Participation } \\
\text { - Academic Progression } \\
\text { - Transition into Work }\end{array}$ \\
\hline
\end{tabular}

Figure 2: Structure and Content of Quality Model 
The structure of the model involves four levels that allow for the operationalisation of quality with different degrees of abstraction. Within the analysed approaches, areas that comprise primary characteristics of institutional actions and processes were specified with a certain variation in the degree of their comprehensiveness. Here, a two-level approach for the definition of quality areas was chosen, and the distinction between an evaluation area and a quality dimension was introduced. This distinction allows for a further specification of dimensions of institutional quality, which serves to increase accessibility of the model, and enables a focus on selective areas, with reference to specific institutional development processes. A quality dimension is a further, more specific, domain of an evaluation area. Quality dimensions comprise thematically related qualities and activities of evaluation areas, and encompass a range of criteria that have been identified as relevant for educational quality in the specific context. Example quality dimensions within the area of Learning \& Teaching are: Quality Classroom Teaching \& Management, Learner Orientation and Holistic Vocational Focus. Quality criteria indicate distinct attributes of institutional and educational quality (Watters, 2015). They may refer to processes, input or output factors, and are specified with reference to institutional and educational objectives. Here, they are conceptualised as complex constructs, generally composed of a range of indicators. An example of a criterion in the dimension Educational Provision \& Curricula would be Demand-Orientation of Course Programme. Indicators serve for specific measurement purposes. Criteria are operationalised by qualitative indicators and-where appropriate-substantiated by quantitative measures. Example indicators for the criterion Employability cover "utilised skills at the workplace (in internships, after final placement)", "employer satisfaction regarding job readiness and actual skill sets", "satisfaction of graduates with trade or occupation acquired" as well as "percentage of graduates entering in designated or related industries" and "percentage of graduates who are in wage employment, self-employed or family business."

Evaluation areas, quality dimensions and related criteria are assumed to have different direct and indirect effects on the quality of individual learning processes. School effectiveness research identified several main influence factors that primarily relate to school context, teachers and instruction (Creemers \& Reezigt, 1996; Scheerens \& Bosker, 1997; Scheerens et al., 2013), mapped in the current approach. Bell et al. (2004) argue that DBR enables the researchers to capture iterative exploration and refinement of the educational elements in different places where learning occurs. With this context, despite the quality dimensions, criteria and indicators are adapted from school context and educational settings; the developed quality model is contextualised, with the intention to analyse and meet quality issues pertaining to (formal) VET institutions in India and not general education.

As has been discussed in the literature review, the majority of learners who graduate from VET institutions are unemployed, even those who enter into the labour market lack the skills expected to perform at the workplace. VET institutions need to monitor institutional ac- 
tions with reference to results and the transition to the (formal and informal) labour market (Tara et al., 2016). Essential for the quality of learning processes and related outcomes, are instructional processes at the classroom level (Creemers \& Reezigt, 1996; Hattie \& Yates, 2014). Teacher performance is related to competence, personal motivation and institutional context conditions (Rowan, 1996; Yukl, 2002). Within the current framework, the quality of teaching and learning at the classroom level is viewed as the core factor for educational outcomes and, in addition, builds the primary service of institutions from an organisational perspective. Quality dimensions that relate to personnel, institutional context, organisational and leadership aspects as well as stakeholder impact are organised around this service, having a direct or indirect impact on the quality of direct teacher-student interaction (Wahlstrom et al., 2010).

\section{Contextual Adaptations in the Model}

Culture and education are complex phenomena (Giorgetti et al., 2017) and education systems are part of the culture of a country. Thus, cultural context is one of the more significant influential factors influencing the functioning of educational institutions, the methods used in the classroom teaching-learning process and teacher-student roles (Akbaş, 2011) and their interactions (Sandoval \& Bell, 2004). The cultural context also affects VET practice and behaviour, as well as outcome of programmes, thus, development of such quality models requires an open approach (Rose, 2005). These considerations are important, as the culture has a significant influence on VET, and value and social attitude to VET in India are different from other countries (Pilz, 2016b; Wessels \& Pilz, 2018). As Rose (1991) recognised, the formulation of a programme or model is best reflected as a creative act rather than a process of copying; therefore, some adaptation is required on account of local circumstances (Rose, 1991). With this backdrop, the quality model in this study was developed, with some adaptation based on the local circumstances and deep understanding of the socio-cultural dimension. The contextual adaptation of the model is illustrated in the following section.

India is a highly diversified country in terms of language, religion and caste systems, and also has particular influence exerted by the traditional hierarchical social, cultural and economic structure (Chauhan, 2009; Wessels \& Pilz, 2018). The inclusive growth strategy of India has aimed at ensuring that individuals across society have equal opportunities in access to education and VET, irrespective of gender, age, caste, ethnicity, religion, socio-economic status and family background, to acquire skills and find employment in the labour market (Goel, 2011; Mehrotra, 2017; World Bank, 2008). Possible students or trainees from the lower ranks of society are often excluded from VET because of their obligation to financially support family members. Furthermore, they often lack general support as well as access to information on VET measures. These considerations are reflected, and some measures are taken, through national policy agendas. The very recent National Policy on Education (MHRD, 2020) document, has also outlined the actions aimed at addressing disparities in ac- 
cess to education and vocational training on the basis of gender, or for any underrepresented groups (MHRD, 2020). Therefore, the researchers perceived "Inclusion, Access \& Equity" as one of the key quality dimensions which is included in the current model, to assess actions of institutions to enable access to VET for the poor, rural population and other disadvantaged groups (World Bank, 2008), by providing necessary information on admission requirements, various scholarship schemes and career counselling services for students.

Often, many of the students and also their parents, particularly from lower social strata, poor families and those from rural regions, are largely unaware of the availability of VET, its relevance, job opportunities, and employability potential. The quality criterion "Participation of Underrepresented Groups" under the aforementioned quality dimension, and indicators such as "participation of underprivileged students", "ratio of female students in different vocational courses" and their graduation rates, are included for measurement.

Similarly, the quality criterion component of "Facilities \& Resources" in the "Institutional Sphere and Context" evaluation area, encompasses available general and specialised facilities, as well as equipment in VET institutions. It involves the process related to utilisation and planned maintenance and service of equipment and facilities. Further, maintaining and managing these resources is equally important and ensures facilities should be safe, in an orderly state and hygienic, and correspond to given standards for learning and working processes. In India, the sanitation and hygiene in educational institutions often does not meet required standards, due to lack of resources and/or inadequate institutional support (Rakesh et al., 2014) and therefore, may pose a risk of communicable diseases (United Nations Children's Fund, 1998). Therefore, the researchers considered this criterion as one of the important aspects in the model, to ensure a conducive learning environment; learners and employees are provided with basic amenities such as clean drinking water, toilets, uninterrupted power supply, as some VET institutions in rural regions, face regular power supply issues (Neroorkar \& Gopinath, 2020; Ramasamy, 2016). The discussion above shows that this model design research approach aimed to capture the iterative exploration and adaptation of quality elements in the model, based on local customisation and relevance (Bell et al., 2004), in line with issues associated with the socio-cultural context of the country.

The overall system as well as individual VET institutions in India display weak links to local companies and occupation related industries (Pilz \& Wiemann, 2020), which results in skill mismatch (Bisht \& Pattanaik, 2020; Majumdar, 2008), outdated curricula and missing links to current occupational practice (Neerorkaar \& Gopinath, 2019; Ramasamy, 2016). A fundamental goal of the first National Policy on Skill Development in 2009 was to intensify the private sector involvement in formal VET measures. Therefore, the National Skill Development Corporation (NSDC), a public-private partnership, was built under supervision of the MSDE (British Council, 2016). The main task of the NSDC is to initiate and coordinate actions and the involvement of the private sector in VET as well as the development of Sector 
Skill Councils. The corporation is involved in curriculum development and the qualification of trainers, and is to function as an information system for the government (MSDE, 2020). However, several initiatives for a higher involvement of the private sector in Indian formal VET, including those related to the NSDC, have not proven successful overall (MSDE, 2016; Pilz, 2016c). The evaluation area "Industry Linkage" takes the engagement of industries and trade on the institutional level into specific consideration. In contrast to systemic approaches to public-private involvement, the model emphasises a bottom-up approach of direct interaction and cooperation between VET institutions and local employers. In addition, it addresses the participation of industry and trade members in consulting and steering activities. An important quality dimension of the area relates to "Placement Coordination \& Monitoring". The dimension subsumes all activities that relate to final placement after graduation and the coordination of in-service training and internships during education and training. Furthermore, it involves the joint coordination and supervision of apprenticeship training under the Apprentices Act. The involvement of industries and trade does also relate to curricula design and adaptations as well as industry exposure through visits and guest lecturers, and is therefore addressed by specific indicators under the criteria "Demand-Orientation of Course Programme" and "Quality School Syllabus", located in the evaluation area "Educational Planning, Provision \& Assessment". A further crucial aspect with regard to actual competencies of teaching-personnel is covered by the indicator "years of practical industry- or trade-related experience" under the criterion "Educational Personnel Qualification". Practical working experience of teachers does not only relate to skills and competencies, but in addition contributes to an enhanced openness from the perspective of personnel, regarding the engagement of industry and trade. These examples do also illustrate the interconnectivity of quality areas and dimensions, and exemplify that education and training quality in VET is always a complex interaction of different factors which call for a comprehensive approach for quality measurement.

\section{Outlook}

The basic aim of the entire study is to develop an approach to measure quality that is tailored to the national context. Following the first research phases described in the sections above, the next step is to evaluate the first version of the quality model in Indian ITIs and Polytechnic Colleges. Institutions for the pretest and following pilot will be located in Delhi and Bangalore. The sample will consist of private as well as governmental institutions at different levels of excellence and configuration, to cover a great variety of VET institutions. As cultural and contextual fit is of major relevance for the study, guaranteed field access, compliance with the qualitative and participative research approach, and the support of the research network 
on site, led to the choice for both geographical regions. In addition, the sample was supposed to explicitly cover two different federal states and urban regions in India.

In the pilot-based implementation, the relevance, and appropriateness, of identified quality dimensions, criteria and indicators to the Indian conditions will be validated. A designbased research approach views a successful innovation as a joint product of the designed intervention and the context (Design-Based Research Collective, 2003). Thus, the approach will be evaluated by the research team under close participation of local stakeholders at different levels (district authorities, school management, teachers, and administrative personnel) with regard to content, feasibility and acceptability. Likewise, relevant data on quality will be collected. It is the advantage of a design-based approach, that it does not only focus on how developed models function in specific settings, to document success or failure, but also on processes and interactions that refine the researchers and practitioners understanding of the phenomena in a natural setting (Bell et al., 2004). Therefore, results from the pilot will be analysed and, the model, as well as the criteria and the measurement parameters, will be further adapted and refined.

The optimised model will be implemented in the field, with substantiated insights on context-specific measurement of quality. The revised and finalised approach will be transferred to a quality analysis toolbox, and made available with open access, on an internet homepage in English, to enable easy access and utilisation by Indian vocational training practitioners. The final scientific results of the developed quality model and instruments will also be disseminated through Indian researchers and relevant political actors. Data on quality collected in the main pilot will provide insights for the development and improvement of the VET system. Furthermore, based on the prospective evaluation of the implementation, recommendations for possible systemic changes to enable a successful future implementation of comprehensive quality management approaches in India may be given.

There are significant limitations in this study. The study is planned only in the selected regions of Indian states; therefore, it is encouraged to examine this quality model in other regions considering the diverse culture and distinct economic development within the country. As Li and Pilz (2019) argue, the success of an educational policy transfer or model, is highly dependent on factors such as the extent of contextual adaptation and complex interactions. Limitations also exist with reference to the assessment of long-term implementation outcomes like impact and sustainability of the current approach The impact of an implemented model has been defined by Alexander (2008) as "the intended and/or unintended consequences of the use of the instrument, especially for those-teachers and learners-to whose activities the instruments are applied" (p.15) and can be differentiated with regard to impact in application, and impact in reporting. While detection of certain effects in the pilot-based quality model implementation is to be expected, and revision of the approach with respect to unintended effects will be undertaken, a comprehensive evaluation of impact with reference 
to effects on quality data and possible institutional development is not feasible within the current research design. The same holds for sustainability, which describes the extent to which an implemented programme is integrated and maintained within an organisation (Proctor et al., 2011). Still, factors that may hinder or contribute to a successful and possibly sustainable implementation can be identified during the pretest and pilot-based implementation and turned into recommendations for future adopters of the model.

Testing the model in two separate institutions is a novel approach and will provide valuable insights. A framework that includes a wide range of input, process, and output factors, including process variables in the area of teaching and learning, has not been implemented in Indian VET yet, which distinguishes the current study from existing non-implemented concepts for quality measurement in India. In such processes, "soft" factors such as key stakeholders in the intervention setting and capacity building activities, are equally important (Li \& Pilz, 2019; Ramasamy \& Pilz, 2019). These prerequisites provide a substantial base for long-term implementation and initiation of institutional development processes on site.

The joint research project allows researchers to gain insights on key quality issues of VET institutions in India, the reiteration process between both Indian and German research partners, while identifying the quality areas and criteria, has provided an opportunity to understand socio-cultural aspects of both the countries, and experience an exchange of knowledge (Pilz et al., 2020). The success of any programme or model, depends on the specific context of the country, particularly cultural values and assumptions (Rose, 2005). Thus, the developed quality model may be implemented in other countries to analyse the quality of VET institutions, with an adequate degree of contextual adaptation and customisation, based on education and training policy and the VET system of the specific country.

\section{Acknowledgement}

The project described here is funded by the German Federal Ministry of Education and Research (BMBF) as "Analysis of Quality in Indian Vocational Education and Training Institutions" (Ref. no 01BF18009A). 


\section{References}

Agrawal, T. (2012). Vocational education and training in India: Challenges, status and labour market outcomes. Journal of Vocational Education \& Training, 64(4), 453-474. https://doi.org/10.1080/13 636820.2012 .727851

Agrawal, T., \& Agrawal, A. (2017). Vocational education and training in India: A labour market perspective. Journal of Vocational Education \& Training, 69(2), 246-265. https://doi.org/10.1080/136 36820.2017.1303785

Ajithkumar, M. U. (2016). Training of teachers: Institutionalising training and development of academic faculty of TVET institutions for realising excellence. In M. Pilz (Ed.), India: Preparation for the world of work (pp. 183-210). Springer. https://doi.org/10.1007/978-3-658-08502-5_10

Ajithkumar, M. U., \& Pilz, M. (2019). Attractiveness of Industrial Training Institutes (ITI) in India: A study on ITI students and their parents. Education and Training, 61(2), 153-168. https://doi. org/10.1108/ET-04-2018-0102

Akbaş, O. (2011). The Role of cultural context in continuing vocational training: A study on auto repairmen in Turkey. Australian Journal of Adult Learning, 51(1), 69-95. https://files.eric.ed.gov/ fulltext/EJ951983.pdf

Alexander, R. J. (2008). Education for all, the quality imperative and the problem of pedagogy. Create pathways to access research monograph, 20. Institute of Education University of London. http:// www.create-rpc.org/pdf_documents/PTA20.pdf

Bell, P., Hoadley, C. M., \& Linn, M. C. (2004). Design-based research in education. In M. C. Linn, E. A. Davis \& P. Bell (Eds.), Internet environments for science education (pp. 73-88). Lawrence Erlbaum Associates Publishers.

Bisht, N., \& Pattanaik, F. (2020). Exploring the magnitude of inclusion of Indian youth in the world of work based on choices of educational attainment. Journal of Economics and Development, 23(2), 128-143. http://doi.org/10.1108/JED-08-2020-0114

Brinkmann, S. (2015). Learner-centred education reforms in India: The missing piece of teachers' beliefs. Policy Futures in Education, 13(3), 342-359. https://doi.org/10.1177\%2F1478210315569038

British Council. (2016). Overview of India's evolving skill development landscape. https://www.britishcouncil.org/sites/default/files/18.10.16_overview_of_skill_landscape.pdf

Broadfoot, P. (2000). Comparative education for the 21st century: Retrospect and prospect. Comparative Education, 36(3), 357-371. https://doi.org/10.1080/03050060050129036

Chakravorty, B., \& Bedi, A. S. (2019). Skills training and employment outcomes in rural Bihar. The Indian Journal of Labour Economics, 62(2), 173-199. https://doi.org/10.1007/s41027-019-00167-8

Chauhan, C. P. S. (2009). Education for all in India: A second look. International Journal of Lifelong Education, 28(2), 227-240. https://doi.org/10.1080/02601370902757091

Creemers, B. P. M., \& Reezigt, G. J. (1996). School level conditions affecting the effectiveness of instruction. School Effectiveness and School Improvement, 7(3), 197-228. https://doi. org/10.1080/0924345960070301

De, D. (2019). Issues and challenges in implementing the skill India movement: Training partner perspective. Worldwide Hospitality and Tourism Themes, 11(1), 54-67. http://doi.org/10.1108/ WHATT-10-2018-0065

Design-Based Research Collective. (2003). Design-based research: An emerging paradigm for educational inquiry. Educational Researcher, 32(1), 5-8. https://doi.org/10.3102\%2F0013189X032001005 
Euler, D. (2014). Design-research - A paradigm under development. In D. Euler \& P. F. E. Sloane (Eds.), Design-based research (pp. 15-41). Franz Steiner Verlag. https:/www.alexandria.unisg. ch/232672/1/DEu-DBR17-37.pdf

European Centre for the Development of Vocational Training. (2009). Continuity, consolidation and change: Towards a European era of vocational education and training, Cedefop reference series, 73. Office for Official Publications of the European Communities. http://www.cedefop.europa.eu/ files/3055_en.pdf

Galvao, M. E. (2014). Making the case for vocational education and training improvement: Issues and challenges. In European Training Foundation (ETF) (Ed.), Quality assurance in vocational education and training (pp. 5-15). ETF. http://pichet-pinit.in.th/wp-content/uploads/2016/08/Qualityassurance-in-VET.pdf\#page $=5$

Giorgetti, F. M., Campbell, C., \& Arslan, A. (2017). Culture and education: Looking back to culture through education. Paedagogica Historica, 53(1-2), 1-6. https://doi.org/10.1080/00309230.2017.1 288752

Goel, V. P. (2011). Technical and vocational education and training (TVET) system in India for sustainable development. UNEVOC. https://unevoc.unesco.org/up/India_Country_Paper.pdf

Hattie, J., \& Yates, G. C. R. (2014). Visible learning and the science of how we learn. Routledge.

Heneveld, W., \& Craig, H. (1996). Schools Count. World Bank project designs and the quality of primary education in Sub-Saharan Africa. World Bank Group. http://documents.worldbank.org/curated/ en/752881468742862189/Schools-count-World-Bank-projects-designs-and-the-quality-of-primary-education-in-sub-Saharan-Africa

Jambo, S., \& Pilz, M. (2017). Perceptions of teachers in industrial training institutes: An exploratory study of the attractiveness of vocational education in India. International Journal of Training Research, 16(1), 4-18. https://doi.org/10.1080/14480220.2017.1403945

Joshi, S., Pandey, G., \& Sahoo, B. K. (2014). Comparing public and private vocational training providers. In S. Mehrotra (Ed.), India's skills challenge: Reforming vocational education and training to harness the demographic dividend (pp. 86-128). Oxford University Press. https://doi.org/10.1093/ acprof:oso/9780199452774.003.0003

Kotamraju, P. (2014). The Indian vocational education and training (VET) system: Status, challenges, and options. Community College Journal of Research and Practice, 38(8), 740-747. https://doi.org/ 10.1080/10668926.2014.897085

Kumar, K. (2016). ITIs/ITCs: Industrial Training Institutes/Industrial Training Centres. In M. Pilz (Ed.), India: Preparation for the world of work - Education system and school to work transition (pp. 65-80). Springer. https://doi.org/10.1007/978-3-658-08502-5_5

Kumar, R., Mandava, S., \& Gopanapalli, V. S. (2019). Vocational training in India: Determinants of participation and effect on wages. Empirical Research in Vocational Education and Training, 11(3), 1-17. https://doi.org/10.1186/s40461-019-0078-y

Lewis, T. (2007). The problem of cultural fit-What can we learn from borrowing the German dual system? Compare, 37(4), 463-477. https://doi.org/10.1080/03057920701366408

Li, J. (2017). Policy Transfer von deutschen Evaluationskonzepten der Berufsbildung nach China [Policy transfer of German evaluation concepts of vocational education and training to China] [Doctoral dissertation]. Springer. https://doi.org/10.1007/978-3-658-18502-2 
Li, J., \& Pilz, M. (2019). Transferring German evaluation policy to China: A prospective evaluation of peer review in TVET. Comparative Education Review, 63(4), 613-632. https://doi. org/10.1086/705425

Majumdar, S. (2008). Workforce development in India: Policies and practices. Asian Development Bank Institute. http://www.esocialsciences.org/Download/repecDownload.aspx?fname=Docume nt130112008230.6895258.pdf\&fcategory=Articles\&AId=1779\&fref=repec

Malik, G., \& Venkatraman, A. (2017). The great divide: Skill gap between the employer's expectations and skills possessed by employees. Industrial and Commercial Training, 49(4), 175-182. https://doi. org/10.1108/ICT-11-2016-0071

Mehrotra, S. (2014a). From 5 million to 20 million a year: The challenge of scale, quality and relevance in India's TVET. Prospects, 44(2), 267-277. https://doi.org/10.1007/s11125-014-9305-2

Mehrotra, S. (2014b). Quantity \& quality: Policies to meet the twin challenges of employability in Indian Labor Market. Indian Journal of Industrial Relations, 49(3), 367-377. http://www.jstor.org/ stable/24546983

Mehrotra, S., Gandhi, A., \& Sahoo, B. K. (2013). Estimating India's skill gap on realistic basis for 2022. Economic and Political Weekly, 48(13), 102-111. https://www.researchgate.net/publication/295598089_Estimating_India\%27s_skill_gap_on_a_realistic_basis_for_2022

Mehrotra, S., Raman, R., Kumra, N., Kalaiyarasan, \& Röß, D. (2014). Vocational education and training reform in India. Business needs in India and lessons to be learned from Germany. Bertelsmann Stiftung. https://www.bertelsmann-stiftung.de/fileadmin/files/BSt/Publikationen/GrauePublikationen/GP_Vocational_Education_and_Training_Reform_in_India.pdf

Mehrotra, V. S. (2017). Vocational education and training in India: Challenges and critical issues. IASSI-Quarterly: Contributions to Indian Social Science, 36(2-3), 290-303. https://web.b.ebscohost. com/ehost/pdfviewer/pdfviewer?vid=0\&sid=85597d97-6bef-42a2-87e1-75c9ada6b6fa\%40pdc-vsessmgr02

Ministry of Human Resource Development. (2019). All India survey on higher education 2018-19. https://www.education.gov.in/sites/upload_files/mhrd/files/statistics-new/AISHE\%20Final\%20 Report\%202018-19.pdf

Ministry of Human Resource Development. (2020). National Education Policy 2020. https://www.education.gov.in/sites/upload_files/mhrd/files/NEP_Final_English_0.pdf

Ministry of Skill Development and Entrepreneurship. (2015). National Policy for skill Development and Entrepreneurship 2015. http://www.skilldevelopment.gov.in/reports-documents/policies/nationalpolicy-skill-development-and-entrepreneurship-2015

Ministry of Skill Development and Entrepreneurship. (2016). Report of the committee for rationalization and optimization of the functioning of the sector skill councils. https://cse.azimpremjiuniversity. edu.in/wp-content/uploads/2018/02/Sharada_Prasad_Report_Vol1.pdf

Ministry of Skill Development and Entrepreneurship. (2018). Annual report 2017-2018: Progressing towards an empowered India. https://www.msde.gov.in/assets/images/annual\%20report/Annual\%20Report\%202017-2018\%20(English).pdf

Ministry of Skill Development and Entrepreneurship. (2020). Annual report. 2019-20. https://www. msde.gov.in/sites/default/files/2020-12/Annual\%20Report\%202019-20\%20English.pdf

Ministry of Skill Development and Entrepreneurship. (2021). ITI count - India all ITIs. https://www. ncvtmis.gov.in/Pages/ITI/Count.aspx 
Nastasi, B. K., \& Hitchcock, J. H. (2016). Mixed methods research and culture-specific interventions. Sage. https://doi.org/10.4135/9781483399959

Neroorkar, S., \& Gopinath, P. (2019). Impact of Industrial Training Institutes (ITIs) on the employability of graduates- A study of government ITIs in Mumbai. Journal of Vocational Education \& Training, 72(1), 23-46. https://doi.org/10.1080/13636820.2019.1575895

Neroorkar, S., \& Gopinath, P. (2020). An employability framework for vocational education and training graduates in India: Insights from government VET institutes in Mumbai.TVET@Asia, 15, 1-18. http://tvet-online.asia/wp-content/uploads/2021/03/03_Neroorkar-and-Gopinath_2020-07-20_ Vorlage-Final-Block-1.pdf

Phillips, D., \& Ochs, K. (2003). Processes of policyborrowing in education: Some explanatory and analytical devices. Comparative Education, 39(4), 451-461. https://doi.org/10.1080/0305006032000162020

Pilz, M. (2016a). India: Preparation for the world of work. Education system and school transition. Springer VS. https://doi.org/10.1007/978-3-658-08502-5_2

Pilz, M. (2016b). Introduction: Why India's focus on preparation for the world of work is highly relevant. In M. Pilz (Ed.), India: Preparation for the world of work (pp. 15-23). Springer VS. https://doi. org/10.1007/978-3-658-08502-5_2

Pilz, M. (2016c). A view from the outside: India's School to work transition challenge - Strengths and weakness. In M. Pilz (Ed.), India: Preparation for the world of work. Education system and school to work transition (pp. 345-357). Springer VS. https://doi.org/10.1007/978-3-658-08502-5_2

Pilz, M. (2017). Policy borrowing in vocational education and training (VET) - VET system typologies and the "6 P Strategy" for transfer analysis. In M. Pilz (Ed.), Vocational education and training in times of economic crisis (pp. 473-490). Springer. https://doi.org/10.1007/978-3-319-47856-2_26

Pilz, M., \& Gengaiah, U. (2019). Teacher training for VET teachers in India. In S. McGrath, M. Mulder, J. Papier \& R. Suart (Eds.), Handbook of vocational education and training (1733-1746). Springer. https://doi.org/10.1007/978-3-319-94532-3_38

Pilz, M., \& Li, J. (2014). Tracing Teutonic footprints in VET around the world? The skills development strategies of German companies in the USA, China and India. European Journal of Training and Development, 38(8), 745-763. http://doi.org/10.1108/EJTD-10-2013-0110

Pilz, M., \& Wiemann, K. (2020). Does dual training make the world go round? Training models in German companies in China, India and Mexico. Vocations and Learning, 14, 95-114 (2021). https://doi.org/10.1007/s12186-020-09255-Z

Pilz, M., Harris, R., Zenner-Höffkes, L., \& Zirkle, C. (2020). Undertaking comparative VET research in international teams: The example of exploring recruitment and training cultures in SMEs in Australia Germany and the United States. In M. Pilz \& J. Li (Eds.), Comparative vocational education research: Enduring challenges and new ways forward (pp. 291-309). Springer VS. https://doi. org/10.1007/978-3-658-29924-8_17

Prakash, B. S., \& Gupta, K. P. (2002). Employability pattern of ITI graduates: A profile of the vocational education system. The Indian Journal of Labour Economics, 45(4). 1267-1276.

Proctor, E., Silmere, H., Raghavan, R., Hovmand, P., Aarons, G., Bunger, A., Griffey, R., \& Hensley, M. (2011). Outcomes for implementation research: Conceptual distinctions, measurement challenges, and research agenda. Administration and policy in mental health, 38(2), 65-76. https://doi. org/10.1007/s10488-010-0319-7 
Rakesh, P., Usha, S., Subhagan, S., Shaji, M., Sheeja, A. L., \& Subair, F. (2014). Water quality and sanitation at schools: A cross sectional study from Kollam District, Kerala, Southern India. Kerala Medical Journal, 7(3), 62-65. https://www.publishmed.com/index.php/KMJ/article/view/329/281

Ramasamy, M. (2016). Demand-driven approaches in vocational education and training: A case study of rural population in South India [Doctoral dissertation]. Springer VS. https://doi.org/10.1007/9783-658-12510-3

Ramasamy, M., \& Pilz, M. (2019). Competency-based curriculum development in the informal sector: The case of sewing skills training in rural South India. International Review of Education, 65(6), 905-928. https://doi.org/10.1007/s11159-019-09810-4

Ramasamy, M., \& Pilz, M. (2020). Vocational training for rural populations: A demand-driven approach and its implications in India. International Journal for Research in Vocational Education and Training, 7(3), 256-277. https://doi.org/10.13152/IJRVET.7.3.1

Rao, K. S., Sahoo, B. K., \& Ghosh, D. (2014). The Indian vocational education and training system: An overview. In S. Mehrotra (Ed.), India's skills challenge: Reforming vocational education and training to harness the demographic dividend (pp. 37-85). Oxford University Press. https://doi.org/10.1093/ acprof:oso/9780199452774.003.0002

Rose, R. (1991). What is lesson-drawing? Journal of Public Policy, 11(1), 3-30. https://doi.org/10.1017/ S0143814X00004918

Rose, R. (2005). Learning from comparative public policy: A practical guide. Routledge.

Rowan, B. (1996). Standards as incentives for instructional reform. In S. H. Fuhrman \& J. A. O’Day (Eds.), Rewards and reform: Creating educational incentives that work (pp. 195-225). Jossey-Bass.

Sandoval, A., \& Bell, P. (2004). Design-based research methods for studying learning in context: Introduction. Educational Psychologist, 39(4), 199-201. https://doi.org/10.1207/s15326985ep3904_1

Scheerens, J., \& Bosker, R. (1997). The foundations of educational effectiveness. Elsevier Science.

Scheerens, J., Witziers, B., \& Steen, R. (2013). A meta-analysis of school-effectiveness studies. Revista de Educación, 36(1), 619-645. https://doi.org/10.4438/1988-592X-RE-2013-361-235

Schneider, S., \& Pilz, M. (2019). The function and institutional embeddedness of polytechnics in the Indian education system. International Journal for Research in Vocational Education and Training, 6(3), 284-308. https://doi.org/10.13152/IJRVET.6.3.5

Steiner-Khamsi, G. (2012). Understanding policy borrowing and lending. Building comparative policy studies. In G. Steiner-Khamsi \& F. Waldow (Eds.), Yearbook of education 2012. Policy borrowing and lending in education (pp. 3-17). Routledge. https://doi.org/10.4324/9780203137628

Tara, N., Kumar, S., \& Pilz, M. (2016). Quality of VET in India: The case of Industrial Training Institutes.TVET@Asia,7,1-17.http://tvet-online.asia/wp-content/uploads/2020/03/tara_etal_tvet7.pdf

United Nations Educational, Scientific and Cultural Organization. (2002). EFA global monitoring Report. Education for all: Is the world on track? UNESCO Publishing. https://unesdoc.unesco.org/ ark:/48223/pf0000129053

United Nations Children's Fund. (1998). A Manual on school sanitation and hygiene, water, environment and sanitation technical guidelines series - No. 5. IRC International Water and Sanitation Centre.

Venkatram, R. (2016). (Technical) Colleges: Technical education in India - The strengths and challenges. In M. Pilz (Ed.), India: Preparation for the World of Work (pp. 81-102). Springer. https://doi. org/10.1007/978-3-658-08502-5_6 
Vogelsang, B., \& Pilz, M. (2020). Conditional factors for training activities in Chinese, Indian and Mexican subsidiaries of German companies. European Journal of Training and Development. Advance online publication. https://doi.org/10.1108/EJTD-04-2020-0066

Wahlstrom, K. L., Seashore Louis, K., Leithwood, K., \& Anderson, S. E. (2010). Investigating the links to improved student learning. Executive summary of research findings. The Wallace Foundation. https://www.wallacefoundation.org/knowledge-center/Documents/Investigating-the-Links-toImproved-Student-Learning-Executive-Summary.pdf

Watters, E. (2015). Promoting quality assurance in vocational education and training. The ETF approach. https://www.etf.europa.eu/sites/default/files/m/B77049AC22B5B2E9C125820B006AF647_Promoting\%20QA\%20in\%20VET.pdf

Wessels, A., \& Pilz, M. (2018). India. International handbook of vocational education and training. P. Grollmann, D. Frommberger, U. Clement, T. Deißinger, U. Lauterbach, M. Pilz, \& G. Spöttl (Eds.). Barbara Budrich. https://www.bibb.de/veroeffentlichungen/de/publication/download/9574

Winterton J. (2012). Varieties of competence: European perspectives. In M. Pilz (Ed.), The future of vocational education and training in a changing world (pp. 455-480). Springer VS. https://doi. org/10.1007/978-3-531-18757-0_25

World Bank. (2008). Skill development in India - The vocational education and training system. World Bank. https://openknowledge.worldbank.org/bitstream/handle/10986/17937/423150India0VET0 no02201PUBLIC1.pdf? sequence $=1$ \&isAllowed $=y$

Yukl, G. (2002). Leadership in organizations (5th ed.). Prentice Hall.

Zenner, L., Kumar, K., \& Pilz, M. (2017). Entrepreneurship education at Indian industrial training institutes: A case study of the prescribed adopted and enacted curriculum in and around Bangalore. International Journal for Research in Vocational Education and Training, 4(1), 69-94. https://doi. org/10.13152/IJRVET.4.1.4

\section{Biographical Notes}

Dr Muthuveeran Ramasamy is a research fellow at the Chair of Economics and Business Education at the University of Cologne in Germany. He obtained his PhD from the University of Cologne. Before his current position, he worked as Project Director at the Vellore Institute of Technology in India. His research interests include international VET with a focus on India, skill development, sociology of education and rural development.

Julia Regel is a research assistant and $\mathrm{PhD}$ candidate at the Chair of Economics and Business Education at the University of Cologne in Germany. Her research interests include international VET research with a focus on India, teaching and learning, and quality development in VET.

Harshil Sharma is a guest researcher in the project QualIndia at the Chair of Economics and Business Education at the University of Cologne in Germany. He is working for the Delhi Government of India as a Chief Minister fellow. Harshil Sharma is also pursuing a doctoral 
degree from the Jawaharlal Nehru University, Delhi. His research areas include: Labour economics, development economics, skill development and political economy.

Dr Anjana Rajagopalan is a guest researcher in the project QualIndia at the Chair of Economics and Business Education at the University of Cologne in Germany. She is working as a policy analyst at the Centre for Budget and Governance Accountability in Delhi. Her PhD at the Jawaharlal Nehru University, Delhi, focused on workforce diversification in India and contemporary challenges.

Prof. Dr Matthias Pilz is Professor of Economics and Business Education at the University of Cologne in Germany and Director of the German Research Center for Comparative Vocational Education and Training (G.R.E.A.T.). His research interests are in international comparative research in VET, transitions from education to employment, and teaching and learning. 